\title{
THE EXTRATERRITORIAL APPLICATION OF ANTITRUST LAWS
}

\author{
Caterina Ventura ${ }^{*}$
}

I. CANADA'S POSITION ON EXTRATERRITORIALITY . . . . . . . . . 461

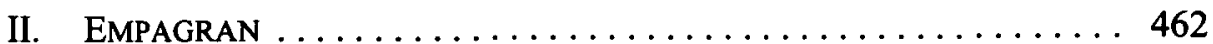

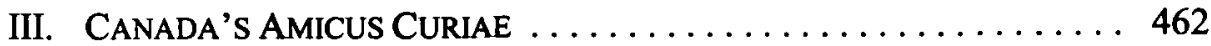

IV. APPLICATION OF THE REASONABLENESS TEST $\ldots \ldots \ldots \ldots \ldots . \ldots 46$

"An Act of Congress ought never to be construed to violate the law of nations if any other possible construction remains"1

Chief Justice Marshall articulated this fundamental canon of U.S. statutory construction, reflective of customary international law, in 1804 in Murray $v$. Schooner Charming Betsy, an admiralty case commonly referred to as the "Charming Betsy" case. As the foreign government representative on this panel, I would like to provide an extraterritorial perspective on the extraterritorial application of domestic law following the Charming Betsy principle.

\section{CANADA's POSITION ON EXTRATERRITORIALITY}

Let me start by saying that Canada does not object to the assertion of extraterritorial jurisdiction per se. Canada exercises extraterritorial jurisdiction pursuant to multilateral treaties for egregious offences such as those found in the Convention against Torture. However, Canada is opposed, in principle, to broad assertions of extraterritorial jurisdiction over Canadian individuals and entities arising out of activities that take place entirely outside of the state asserting jurisdiction. This assertion of jurisdiction interferes with the sovereignty of governments and is not in conformity with international law. Under international law, the limitations on the extent to which any single nation can extend its own jurisdiction are generally recognized as flowing from the sovereignty and equality of nations.

* Foreign Affairs Canada in Ottowa, Deputy Director, United Nations Human Rights and Economic Law Division. This article is a revised reproduction of oral remarks presented at the International Law Weekend 2004, held at the House of the Association of the Bar of the City of New York, from October 20 to $22,2004$.

1. Murray v. Schooner Charming Betsy, 6 U.S. 64, 118 (1804). 


\section{EMPAGRAN}

It was on the basis of this principle that Canada intervened as amicus curiae in the F. Hoffmann-Laroche Ltd et al v. Empagran case (referred to as Empagran) heard by the United States Supreme Court on April 26, 2004, decision rendered on June 14, 2004.

I will be focusing my comments on the Empagran decision as it articulates the Supreme Court's views on the extraterritorial application of antitrust law. It also cited the Canadian brief and supported the Canadian position.

The Empagran case involved vitamin sellers (a vitamin cartel) around the world that agreed to fix prices, leading to higher vitamin prices in the U.S. and independently to higher prices in other countries. Foreign purchasers filed a class action under U.S. antitrust law (the Sherman Act) alleging the vitamin sellers had engaged in a price-fixing conspiracy. The Court stated that a purchaser of the vitamins in the United States could bring a claim under U.S. antitrust legislation. However, the plaintiffs in the Empagran case never asserted they purchased vitamins in the United States. Therefore, the Court was essentially left to determine first whether the conduct in question involved trade or commerce with foreign nations and if so, did the conduct have a "direct, substantial, and reasonably foreseeable effect" on domestic commerce. ${ }^{2}$ These were the criteria to determine if the Sherman Act would apply.

In its consideration of the issue, the Court referred to the amici curiae filed by Germany, Canada, Japan, and the United States.

\section{CANADA's Amicus CURIAE}

Before I get to the Court's analysis of the application of the Sherman Act, I would like to give you a sense of the perspective Canada presented to the Court. The Government of Canada submitted that recognized legal principles militate against the broad extraterritorial application of the Sherman Act under the circumstances of this case. United States legal principles limit the exercise of extraterritorial jurisdiction over non-nationals when such exercise is "unreasonable." These principles parallel principles of international law and comity that are recognized and applied by Canada and other nations.

The legal principles that foreclose the unreasonable exercise of extraterritorial jurisdiction had ready application to the facts of this case. The four factors applied by U.S. courts to determine the reasonableness of an exercise of extraterritorial jurisdiction relate to a nexus with U.S. territory, to a nexus with U.S. nationals, to other countries' interest in regulation, and to conflict with other countries regulation. Canada argued, that from the perspective of the United States, the respondents were foreign nationals. The transactions on

2. F. Hoffmann-La Roche Ltd. v. Empagran S. A., 124 S. Ct. 2359, 2363 (2004). 
which they base their claims occurred solely in foreign commerce and had no effects in the United States or on U.S. commerce. Canada and other nations have a strong interest in regulating, and do regulate the type of activity on which respondent's claim are based. In Canada, members of the vitamin cartel were prosecuted under the Competition Act in respect of criminally sanctioned cartel activity and its domestic effects. Prosecutions also occurred in the European Union, Australia, and the U.S. Record fines were levied within these jurisdictions against the cartel members.

The laws of some countries, including those of Canada and the U.S., enable private parties to seek compensation in a civil suit for damages for financial injury suffered as a result of the activity of cartel members in the domestic market. While Canada, and most other countries, allow recovery only of the actual damages suffered, plaintiffs in the U.S. are entitled to treble damages if their suit is successful. The assertion of U.S. jurisdiction would conflict with Canada's enforcement of its own antitrust regime as it would, inter alia, undercut Canada's immunity program that gives cartel members incentive to report their illegal activity and cooperate with other authorities, because criminal immunity from Canadian authorities would come at the increased cost of punitive treble damages under U.S. law for its worldwide transactions. Canada concluded that it would be unreasonable for U.S. courts to exercise the jurisdiction requested by the foreign plaintiffs.

\section{APPLiCATION OF THE REASONABLENESS TEST}

The Court concluded that the Sherman Act did not apply. Citing, inter alia, the Charming Betsy, the Court commenced its analysis with the principle that it ordinarily construes ambiguous statutes to avoid unreasonable interference with the sovereign authority of other nations. This allows potentially conflicting laws of different nations to work together. The Court found that application of U.S. antitrust laws to foreign anticompetitive conduct to redress domestic antitrust injury that foreign anticompetitive conduct has caused is reasonable. It is however not reasonable to apply U.S. law when it is foreign harm alone that gives rise to the plaintiff's claim. The Court asked why should American law supplant Canada's or Great Britain's or Japan's own determination on how to protect their own people from anticompetitive conduct engaged in by their own companies. It noted that several nations filed briefs (Germany, Canada, Japan) arguing that applying U.S. remedies would unjustifiably permit the German, Canadian, and Japanese citizens to bypass their own less generous remedial schemes and that permitting foreign plaintiffs to pursue private treble damages remedies would undermine foreign nations own antitrust enforcement policies by diminishing foreign firms incentive to cooperate with antitrust authorities in return for prosecutorial amnesty. 
The Court then concluded that "if America's antitrust policies could not win their own way in the international marketplace for such ideas, Congress, we must assume, would not have tried to impose them, in an act of legal imperialism, through legislative fiat."3

The Supreme Court could not have been more clear on the facts. Statutes are to be construed to avoid unreasonable interference with other nations sovereign authority-effectively a restatement of the Charming Betsy, customary international law-200 years later. 